\title{
RECENZJA MONOGRAFII: Р.В. БЕЛЮТИН, ПРАГМАСЕМАНТИЧЕСКИЕ И ЛИНГВОМЕНТАЛЬНЫЕ ПРОЕКЦИИ НЕМЕЦКОГО СПОРТИВНОГО ДИСКУРСА, СМОЛЕНСК: ИЗДАТЕЛЬСТВО СМОЛГУ, 2019. 336 S. ISBN 978-5-88018-641-9
}

\author{
Andrzej Narloch
}

Sport jako jeden $\mathrm{z}$ fenomenów kulturowych przyciąga zainteresowanie szerokich mas społeczeństwa. Wraz z rozpowszechnieniem sportu obserwujemy również dynamiczny rozwój dyskursu sportowego, któremu poświęcona jest recenzowana monografia. Przedmiotem niniejszego opracowania jest kompleksowe przebadanie niemieckiego dyskursu sportowego $\mathrm{w}$ aspektach pragmalingwistycznym i kognitywnym. Monografia została napisana w języku rosyjskim. Autor na wstępnie sprecyzował przedmiot swoich badań, uzasadniając wybór tematyki. Opisana została baza naukowo-metodologiczna, stan badań, a także znaczenie teoretyczne i praktyczne niniejszej pracy. Oprócz wstępu, monografia składa się z pięciu rozdziałów (s. 14-266), podsumowania (s. 267-272), wykazu literatury przedmiotu (str. 273-297) oraz spisu źródeł (s. 297-336).

Podejmowana problematyka badawcza wyznacza niejako konieczność odniesienia się do istniejących już opracowań naukowych dotyczących badań nad dyskursem. Założenia teoretyczne bazują na doświadczeniach zarówno językoznawstwa rosyjskiego, jak i zachodnioeuropejskiego, zwłaszcza niemieckiego. W rozdziale pierwszym Autor podkreśla podwójną naturę tego fenomenu, określając dyskurs jako "mowę zanurzoną w życiu". Wskazuje się również na nierozerwalny związek dyskursu jako sytuacji komunikacyjnej z czynnikami społecznymi, kulturowo-histo- 
rycznymi, ideologicznymi, psychologicznymi i in. W dalszej części rozdziału odnajdujemy opis konceptu „Sport” na płaszczyźnie społeczno-komunikatywnej i kulturowej. Takie podejście wydaje się wskazane ze względu na możliwość uwzględnienia szerszej perspektywy badawczej. Sport zdolny jest do kształtowania politycznej przestrzeni narodu, wpływu na upodobania społeczne, sympatie i antypatie. Waga sportu polega na jego wpływie na inne sfery działalności człowieka. Można wręcz mówić o usportowieniu współczesnego życia i jego silnym oddziaływaniu na zjawiska społeczno-kulturowe, w tym gospodarkę, politykę, sztukę, język. Autor uważa sport za wewnętrznie zorganizowany, wieloplanowy i złożony koncept kulturowy, określając go mianem megakonceptu. Swoje rozważania opiera na omówieniu najważniejszych prac z zakresu dyskursu sportowego. Szczególną uwagę Autor zwraca na funkcjonowanie dyskursu sportowego w sytuacjach komunikacyjnych, wskazując na istnienie określonego kodu językowego wewnątrz określonej grupy. Istotną rolę odgrywa również $\mathrm{w}$ języku sportu metafora i proces jej transmisji do innych sfer komunikacji. W dalszej części opracowania Autor konstytuuje cechy dyskursu, jego strukturę oraz zasięg komunikacyjny. Pośród głównych cech wymienia jego złożoność włączającą inne subdyskursy, trudność profilowania uczestników (grup docelowych) zwłaszcza w odniesieniu do kibiców. Inną ważną cechą jest wzajemne przeplatanie z innymi dyskursami prowadzące do heterogeniczności gatunkowej. Autor opisuje pragmatyczne i semantyczne podejście do analizy dyskursu jako efektywnego sposobu potwierdzania faktów i twierdzeń lingwokognitywnych. Dlatego przyjęta $\mathrm{w}$ monografii kognitywna projekcja $\mathrm{w}$ analizie dyskursu realizowana jest poprzez przebadanie wchodzących w jej strukturę konceptów, ram interpretacyjnych czy innych mentalnych jednostek reprezentacji wiedzy. Wydaje się zatem, że przyjęte przez Autora modelowanie kognitywne jest właściwą metodą badania mentalnej sfery człowieka i pozwoli na wniknięcie w istotę takich zjawisk jak uzyskanie, gromadzenie, obróbka, przechowywanie, reprezentacja i przekazywanie wiedzy w dyskursywnej aktywności człowieka. Wynika z tego, że zagadnienie kategoryzacji świata przez przedstawicieli niemieckiej lingwistyki kulturowej z perspektywy dyskursu sportowego pomoże zrozumieć, jak funkcjonuje kolektywna świadomość w komunikacji sportowej.

Autor omawia prace najważniejszych badaczy z dziedziny dyskursologii, m.in. F.L. Jahna, O. Eckardta, W. Haubricha, H. Dankerta, A. Burkhardta, P. Schlobinskiego, J. Heila, J. Borna, Ch. Marxa, S. Krankenhagena i in. Pokrótce zaprezentowano prace innych językoznawców, w tym polskich i rosyjskich badaczy: J. Taborka, A. Tworka, L. Zielińskiego, A.G. Gołodova, L.A. Komleva, W.I. Szuwałowa, F. Zimmlera i in., czy badania rosyjskich językoznawców niemieckiego dyskursu sportowego autorstwa A.B. Zilberta, E.G. Małyszewej, A.A. Elistratova.

Badany dyskurs sportowy obejmuje szereg zagadnień włączających nie tylko język środków masowego przekazu, lecz i dyskursywne fragmenty języka sportowców, trenerów, kibiców, komentatorów, sędziów. W dalszej części pracy podkreśla 
się złożoność dyskursu sportowego, motywując ją trudnościami w jednoznacznej identyfikacji pary uczestników ze względu na dużą ilość grup docelowych. Dyskurs sportowy zaprezentowany został z jednej strony na płaszczyźnie pragmatycznosemantycznej, uwzględniającej oprócz samej wypowiedzi dodatkowe czynniki takie, jak: kto mówi, kiedy, w jakiej sytuacji itd., z drugiej strony - lingwokognitywnej zorientowanej na przeanalizowanie dyskursu $\mathrm{z}$ punktu widzenia wchodzących $\mathrm{w}$ jego strukturę konceptów, ram pojęciowych czy też innych mentalnych jednostek reprezentacji wiedzy.

Analiza kognitywna dyskursu sportowego zakłada uwzględnienie metafory i metaforycznego modelowania konceptów realizowanych w poszczególnych typach komunikacji. Powyższemu został poświęcony rozdział drugi. Po wstępie dotyczącym teorii metafory jako kognitywnego zjawiska odnoszącego się do uniwersalnych gnoseologicznych mechanizmów następuje omówienie poszczególnych modeli. „Sport” stanowi sferę domeny docelowej, której strukturyzacja następuje dzięki importowaniu do niej innych sfer pojęciowych. Wyróżniono 6 takich sfer: Religia, Wojna, Teatr, Technika, Bajka, Erotyka. Autor wykazuje, że domena docelowa korzysta również z zasobów własnej domeny, przekierowując koncepty jednej subdyscypliny do innej, na przykład, ze sfery boksu do sfery piłki nożnej. Obserwuje się również „migracje” konceptów innych subdyskursów (jeździectwo, lekkoatletyka, koszykówka, kolarstwo i in.) do nowego dla nich pola komunikacyjnego. Z innych pól, jak wykazuje Autor, najczęściej korzysta dyskurs piłki nożnej. Szczegółowo i na podstawie dużej ilości przykładów zaprezentowano poszczególne modele. Zwrócono uwagę na znaczące zbliżenie się konceptualnej sfery „Piłka nożna” do dyskursu religijnego oraz wysoką kreatywność niemieckich kibiców w tworzeniu metafor religijnych niejednokrotnie czerpiących swoje źródła w motywach biblijnych. Autor omawia również metafory orientacyjne (zgodnie z założeniami teorii metafory Lakoffa i Johnsona), ograniczając się do analizy jednego typu modelu (Góra - Dół). Wykazano również występowanie różnic w modelowaniu metafory w niemieckim dyskursie sportowym w stosunku do jego rosyjskiego odpowiednika, gdzie w niektórych przypadkach wykorzystuje się inne typy metafor bądź konstrukcje opisowe. Rozdział drugi wykazał, że konceptosfera „Piłka Nożna” zajmuje szczególne miejsce w niemieckim dyskursie sportowym, gdyż właśnie ta dyscyplina przyciąga do siebie metafory z innych dziedzin.

Przedmiotem analizy rozdziału trzeciego są pragmatyczno-semantyczne profile niemieckiego dyskursu sportowego, zwłaszcza konceptualne modele metonimiczne, które Autor rozumie jako dwukomponentowe struktury kognitywne, gdzie relacje pomiędzy obiektami konceptualnymi budowane są na podstawie mechanizmu zamiany wraz $\mathrm{z}$ profilowaniem $\mathrm{w}$ konceptualnej strukturze jakiejś ramy pojęciowej. O ile w ogólnym języku niemieckim metonimia została szeroko i dokładnie opisana, to $\mathrm{w}$ sferze komunikacji specjalistycznej dopiero $\mathrm{w}$ ostatnich latach pojawily się prace $\mathrm{z}$ tego zakresu ukierunkowane na systemowe przestudiowanie metonimicznej 
reprezentacji rzeczywistości. Autor opisuje zebrany materiał, opierając się na podziale tematycznym wokół określonej sfery konceptualnej. Odnotowano dość powszechne występowanie nazw w formie skróconej czy też nazw metonimicznych na podstawie derywacji semantycznej opartej na nazwach barw klubowych. Do innych odnotowanych źródeł nazw drużyn piłkarskich należą symbolika herbów klubowych bądź historia powstania klubu. Podkreślenia wymaga fakt wykorzystywania idei ilości w przeniesieniach metonimicznych, niosących szczególną funkcję semantyczną, tj. określającą podmioty, przedmioty, zjawiska, fakty z życia sportowego. Wysoka częstotliwość tworzenia znaczeń metonimicznych w niemieckim dyskursie sportowym świadczy o tym, że ów mechanizm przedstawienia, opisu i interpretacji konceptów sportowych jest silnie zakorzeniony w indywidualnej i zbiorowej świadomości niemieckiej. Odnotowano wykorzystywanie zarówno uniwersalnych przesunięć referencyjnych, jak i dyskursywnie specyficznych, których istnienie uwarunkowane jest szczególną wiedzą zawodową, priorytetami czy wartościami. Badanie dyskursu sportowego ujawniło również występowanie hiperboli, która funkcjonuje równolegle z innymi środkami stylistycznymi. Najczęściej znajduje ona swoje odbicie w połączeniu $\mathrm{z}$ metaforą, porównaniem, epitetem. W rozdziale trzecim odnajdujemy również analizę nominacji antroponimicznych. Analiza onimów z zakresu języka sportu pozwoliła Autorowi na wyciągnięcie zasadniczego wniosku, że większość nominacji można uznać za „magazyn” pamięci kolektywnej. Najbardziej rozpowszechnione przypadki funkcjonowania antroponimów obejmują interdyskursywne zapożyczenia antroponimów, włączenie antroponimów sportowych w teksty o charakterze aluzyjnym, wykorzystywanie antroponimów sportowych w dyskursach nie związanych z konceptosferą „Sport”, „wewnętrzne importowanie” antroponimów ze sfery „Sport” z jednej grupy tematycznej do innej, czy ich zapożyczenia w obrębie tej samej dziedziny. Autorowi monografii nie uszedł uwadze również pragmatyczno-semantyczny aspekt koloru w dyskursie sportowym. Jego uwzględnienie wydaje się istotne $\mathrm{w}$ kontekście braku prac poświęconych kolorystycznemu obrazowi świata w dyskursie sportowym. Jądro konceptu „Kolor” tworzy znaczenie 'nieoficjalnych nazw klubu, organizacji, zrzeszen'. Oprócz tego Autor wyróżnia kilka pozostałych przypadków użycia koloratywów w omawianym dyskursie. Należą do nich: przezwiska sportowców i drużyn, decyzje głównego arbitra, ataki werbalne, wyrażanie emocji. Przy czym należy zaznaczyć, że nominacje kolorystyczne zdolne są do wyrażania nie tylko kolorystycznych, lecz i nie związanych bezpośrednio z kolorem pojęć sportowych. Do ciekawych mechanizmów tworzenia dyskursu sportowego należy pragmatyczno-semantyczna zasada ,uproszczenie przez abstrakcję" omówiona na podstawie słowa Ding, które posiada szerokie możliwości semantyczne i zdolne jest do zastępowania wielu konceptów sportowych. Rozdział trzeci kończy analiza tekstów precedensowych i kategorii intertekstualności.

Rozdział czwarty został poświęcony omówieniu dyskursu kibiców i innych wzorców zachowań w sportowej subkulturze kibicowskiej. Autor odnotowuje nie- 
wielką ilość prac podejmujących zagadnienie dyskursu kibiców w rosyjskim językoznawstwie i ograniczających się z reguły do pojedynczych opracowań w porównaniu z badaniami niemieckiego dyskursu kibiców. W przeciwieństwie do trzeciego w rozdziale czwartym dokonano przeglądu dyskursu kibiców na płaszczyźnie etnolingwokulturowej. Mimo że Autor konfrontuje niemiecki dyskurs kibiców z rosyjskim, to dokonuje tego tylko w niewielkim stopniu i dopiero pod koniec rozdziału. Sporo miejsca poświęcono omówieniu społecznych opozycji binarnych, a zwłaszcza opozycji „Swój - Obcy”. Opozycja ta staje się niezmiernie istotna dla subkultury kibicowskiej i przejawia się w wielu sytuacjach komunikacyjnych. Analiza lingwokognitywna wykazała, że opozycja „Swój - Obcy” otrzymuje swoistą konceptualizację o zwiększonym wykładniku wartościowania i tendencji do polaryzacji. Odnotowało również znaczną labilność kategorii semantycznej „Swój - Obcy”. Autor wykazał również, że w zależności od określonych okoliczności ocena swojego i obcego świata może zmieniać się radykalnie. W dalszej części rozdziału następuje prezentacja funcjonalno-pragmatycznej typologii przyśpiewek i pieśni kibicowskich, które stanowią centralny gatunek tego dyskursu. Charakteryzują się one sporym potencjałem, zwłaszcza w dziedzinie badań modusów kognitywnych, emocjonalnych, społecznych, komunikacyjnych w ujęciu antropocentrycznym. Zaproponowana typologia tekstów przyśpiewek i pieśni kibicowskich opiera się na podziale intencjonalnym (illokutywnym). Autor wyróżnia szereg rodzajów tego typu tekstów: inspirujące, solidaryzujące, dyrektywne, chwalebne, dystansujące, dyskredytujące i in. Analiza została przeprowadzona $\mathrm{w}$ rzetelny sposób i wykazuje dużą orientację Autora w omawianej tematyce. W monografii skupiono się również na tzw. „fanzinach” czasopismach wydawanych przez kibiców, które charakteryzują się jednoczesnym wykorzystaniem dyskursu potocznego i komunikacji pisemnej. Autor szczególną uwagę zwrócił na tytuły wydań mających charakter terminologiczny i żargonowy. Jednak, w mojej opinii, zabrakło szerszego ujęcia językowej strony fanzinów. Skupienie się tylko na tytułach i wybranej leksyce dało pewien ogólny, lecz niepełny, wycinek komunikacji kibicowskiej. W dalszej części rozdziału omawia się sytuację dysonansu kognitywnego w dyskursie kibiców sportowych. Uznaje się, że obraz świata kibiców piłkarskich jest pełen sprzeczności powstałych przez relacje dysonantyczne na różnych poziomach. Obserwacje poczynione przez Autora pokazują, że tworzone i rozwijane są własne, specyficzne scenariusze dysonansu kognitywnego. Zaprezentowane przykłady w pełnej mierze potwierdzają założoną tezę, że u człowieka występują takie kognitywne elementy, które są sprzeczne z rzeczywistością. Scenariusze te dotyczą sytuacji opisujących na przykład niezadowolenie kibiców z wyników drużyny lub działań zarządów klubu itd. Autor słusznie odnotował, że powstanie dysonansu kognitywnego może być uwarunkowane względami kulturowymi, różnicami w sposobach konceptualizacji, kategoryzacji, obiektywizacji, oceny rzeczywistości przez przedstawicieli poszczególnych grup etnicznych. W dalszej części rozdziału zaprezentowano na przykładzie dwóch klubów piłkar- 
skich Borussia i Schalke 04 funkcjonowanie zachowań komunikacyjnych subdyskursu kibiców. Autor po krótkim wstępie dotyczącym genezy konfliktu między klubami, przechodzi do prezentacji szeregu przykładów pokazujących relacje obu klubów jako walkę dwóch religii. Oprócz tego subdyskurs zawiera pokaźną porcję negatywnie wartościującej leksyki, odwołuje się do metafory wojny, słownictwa fekalnego, a profilowanie nierzadko następuje wokół konceptu „Nienawiść”. Werbalna konfrontacja dwóch klubów dokonuje się na płaszczyźnie wypowiedzi podkreślających unikalność, przewagę czy miłość do klubu. Autor odnotował również zjawisko tabuizacji oficjalnej nazwy przeciwnego klubu przez kibiców drużyny przeciwnej. W zamian tworzone są nazwy będące wynikiem gry językowej, przekształceń formalnych, w wyniku których nowo powstała nazwa nabiera negatywnego wartościowania. Agresja słowna odgrywa dużą rolę w komunikacji subkultury kibicowskiej. Podział agresji werbalnej został oparty o klasyfikację E.I. Szejgał. Należy pochwalić Autora za obszerną prezentację materiału egzemplifikacyjnego prezentującego porównanie ataków werbalnych omawianych drużyn piłkarskich. Wnioski sprowadzają się do konstatacji, że w celu wyrażenia krytyki, wyśmiania, ironii kibice obu klubów stosują przemyślane metody, przytaczają negatywne informacje, tworzą negatywne wartościowanie podane w ładnym „opakowaniu”. W tym celu wykorzystuje się dyskurs gospodarczy, matematyczny, erotyczny, grę słów opartą na wieloznaczności leksemów, które z kolei inicjują podwójny sens. Interesujące - jak zauważa Autor - jest profilowanie konfrontacji dwóch klubów z wykorzystaniem elementów świata bajkowego i fantastycznego.

Komunikacja niemieckich i rosyjskich kibiców piłkarskich została skonfrontowana ze sobą pod koniec rozdziału czwartego. Mimo że Autor poświęca tej problematyce niewiele miejsca, wydaje się być ona szczególnie interesująca, gdyż zestawia ze sobą dwa konceptualne światy. Głównym celem tej części - jak pisze Autor - jest wykrycie uniwersalnych i specyficznych mechanizmów funkcjonowania obu dyskursów u przedstawicieli badanej grupy społecznej. Zebrany materiał - teksty piosenek i przyśpiewek - został przebadany pod kątem występowania lub braku określonych markerów illokutywnych. Autor odnotował sporo podobieństw w dyskursie niemieckim i rosyjskim. Oprócz tego ustalił różnice, na przykład, wykorzystywanie przez niemieckich kibiców dialektalnych wariantów języka, czego nie odnotowano w dyskursie rosyjskim. Niemiecki dyskurs sportowy wyróżnia się sięganiem do zasobów językowych angielszczyzny czy wykorzystywaniem konceptów religijnych do projekcji metaforycznych w językowym obrazie świata przedstawicieli danej subkultury. Natomiast istnieje wiele wspólnych mechanizmów antonomazyjnego tworzenia słownictwa w obu językach. Modele zachowań komunikacyjnych kibiców w obu krajach pod wieloma względami są jednak zbieżne.

Rozdział piąty koncentruje się wokół sfery konceptualnej „Sport” w ujęciu komunikacji interdyskursywnej i interkulturowej. Wybór ten został zapewne podyktowany koniecznością przeanalizowania wpływu dyskursu sportowego na komunika- 
cyjną organizację innego typu tekstów. Uznaję słuszność takiego podejścia, gdyż „usportowienie” języka niemieckiego do tej pory nie zostało należycie przebadane. Autor odkrywa semantyczne możliwości konceptu „Sport” dzięki metaforycznemu podejściu ukierunkowanemu na udzielenie odpowiedzi, jak funkcjonuje świadomość człowieka, w jaki sposób konceptualizuje otaczający świat. Pokazano na wybranych przykładach usportowienie języka w takich dziedzinach jak socjologia, statystyka, zoologia. Jak się okazuje, włączenie metafory sportowej w ogólnie przyjęty kognitywny, kulturowy i językowy kod niemieckiego obrazu świata ma dużą perspektywę poznawczą. W związku z tym, szczególnie istotna w tym rozdziale okazała się prezentacja bazowych modeli metaforycznych. Wykorzystanie dyskursu sportowego wzbogaca inne dyskursy na poziomie aksjologicznym, może służyć jako narzędzie własnej lub ideologicznej prezentacji, być środkiem samoidentyfikacji, manipulacji, zniesławienia, zarządzania, zbliżenia, propagandy, agitacji, reklamy itd. Jak wykazuje Autor, sfera pojęciowa „Sport” staje się najbardziej produktywnym źródłem wartościowania współczesnej metafory politycznej, a model metaforyczny „Polityka to Sport" zyskał popularność wśród wielu uczestników komunikacji - przedstawicieli partii, dziennikarzy, analityków, działaczy społecznych, członków rządu, czego dobrym przykładem są przytaczane przez Autora fragmenty wypowiedzi kanclerz Niemiec A. Merkel. Aktywne funkcjonowanie metafory sportowej odnotowuje się również w dyskursie o gospodarce, a zwłaszcza w tekstach o charakterze reklamowym, gdzie metafora podporządkowana jest nadrzędnej funkcji perswazyjnej. Autor wyróżnił również inne sfery funkcjonowania metafory sportowej, w tym „Oświatę”, „Gender". Ta ostatnia znajduje szerokie zastosowanie, szczególnie w celu wyrażania znaczeń leżących nierzadko $\mathrm{w}$ sferze tabu bądź eufemizacji pewnych określeń. Sfera relacji genderowych, wzajemnych relacji płci, zgodnie z obserwacjami Autora, realizowana jest za pomocą żartów i anegdot, wykorzystujących grę językową, podwójne kodowanie sensów.

Słuszną propozycją wydaje się być porównanie tego, co wspólne i różne w metaforycznych projekcjach niemieckiego i rosyjskiego dyskursu sportowego. Ma to szczególne znaczenie w świetle pomyślnej komunikacji międzykulturowej we współczesnym świecie ogarniętym procesami globalizacji i integracji, w którym kluczową rolę może odgrywać jednostka świadoma różnic i podobieństw międzykulturowych. Badania Autora wykazały występowanie w niemieckim i rosyjskim dyskursie sportowym jednakowych modeli metaforycznych zarówno wychodzących poza przestrzeń komunikacyjną swojego konceptu „Sport” (dyskurs sportowy domena źródłowa), jak i obsługujących „wewnątrz” dyskurs (dyskurs sportowy domena docelowa). Zaprezentowane przykłady w obu językach potwierdzają końcowe wnioski. Pod koniec swoich rozważań Autor zajmuje się specyfiką przekładu metafor w niemiecko-rosyjskiej sportowej przestrzeni językowej. Różne konceptualizacje otaczającej rzeczywistości za pomocą wyrażeń metaforycznych, jak udowadnia Autor, nierzadko powodują, że przekład dosłowny staje się niemożliwy. Na kon- 
kretnych przykładach wymieniono trudności wynikające z inkorporowania metafor w przestrzeń „innej” mentalności.

Podsumowując, niniejsza publikacja stanowi kompleksową analizę niemieckiego dyskursu sportowego. Autor wykazał, że badany dyskurs jest zjawiskiem złożonym i wieloaspektowym. W planie strukturalnym dyskurs sportowy opiera się na czterech głównych składowych (terminologia sportowa, żargon sportowy, język sportowych mass mediów, język kibiców). Wszystkie składowe dyskursu są powiązane ze sobą i wzajemnie uzupełniają swoje zasoby językowe. Głównym osiągnięciem publikacji jest prezentacja na szerokim materiale pragmasemantycznego modelu opisu niemieckiego dyskursu sportowego. Zaprezentowane wnioski pod koniec każdego rozdziału stanowią dobre uzupełnienie prezentacji materiału empirycznego. Styl i język pracy nie budzą zastrzeżeń. Recenzowana monografia jest ciekawą propozycją na rynku wydawniczym i zasługuje na uwagę ze strony czytelników zainteresowanych językiem sportu, dyskursem czy procesami metaforyzacji języka.

\section{Bibliografia}

Jahn, F.L. 1816. „Die Deutsche Turnkunst zur Einrichtung der Turnplätze”. URL: http://www.staff. unigiessen.de/gloning/tx/jahntusp.htm

Eckardt, S. 2016. Fußballkrimi. Das beste aus 20 Jahren. Der tödliche Pass. Göttingen: Verlag die Werkstatt.

Haubrich, W. 1963. Die Metaphorik des Sports in der deutschen Gegenwartssprache. Köln: Dissertation.

Dankert, H. 1969. Sportsprache und Sportkommunikation, Tübingen: Vereinigung fur Volkskunde.

Burkhardt, A. 2006. "Sprache und Fußball". Muttersprache 116. 53-73.

Schlobinski, P. 2014. Grundfragen der Sprachwissenschaft. Göttingen: Vandenhoeck und Ruprecht.

Heil, J. 2012. Die Rhetorik des Spitzensports. Berlin/Boston: Walter de Gruyter Verlag.

Born, J. i Th. Gloning. (red.) 2015. Sport, Sprache, Kommunikation, Medien. Interdisziplinäre Perspektiven. Gießener elektronische Bibliothek.

Marx, Ch. 2018. Der springende Punkt ist der Ball. Die wundersame Sprache des Fußball. Berlin: Dudenverlag.

Krankenhagen, S. i H. Rothenpieler. 2018. Die Poesie des Fußballs. Von Abwehrschlachten, Schönspielern und Tikitaka. Berlin: Aufbau Verlag.

Taborek, J. Tworek, A. Zieliński L. (red.) 2012. Sprache und Fußball: im Blickpunkt linguistischer Forschung. Hamburg: Verlag Dr. Kovač.

Голодов, А.Г. 2007. Проблемы разговорности в специальной лексике (на материале немецкого языка футбола): автореф. дис. ... д-ра филол. наук: 10.02.04, Москва.

Комлева, Л.А. Функционирование прецедентных имен в спортивном дискурсе (на материале спортивных автобиографий и мемуаров). URL: http://www.lib.csu.ru/vch/172/011.pdf

Шувалов, В.И. 1991. Использование спортивной метафорики в современной немецкоязычной печати. //Вопросы функциональной лексикологии. Москва. 31-36.

Зиммлер, Ф. 1991. Функциональные и синтаксические особенности спортивных текстов [на материале нем. Яз.] // Языковые единицы в речевой коммуникации. Ленинград. 93-105.

Зильберт, А.Б. 2001. Спортивный дискурс: точки пересечения с другими дискурсами: Проблемы интертекстуальности // Язык, сознание, коммуникация. Москва: Вып. 103-112. 
Малышева, Е.Г. 2011. Русский спортивный дискурс: теория и методология лингвокогнитивного исследования: дис. ... д-ра филол. наук: 10.02.01. Омск.

Елистратов, А.А. 2009. Именная нетерминологическая лексика спорта. // Вестние Челябинского государственного университета. №34 (172). Филология. Искусствоведение. Вып. 36. 26-32.

Лакофф, Дж. 1990. Джонсон, М. Метафоры, которыми мы живем // Теория метафоры. Ред. Н.Д. Арутюнова, М. А. Журинская, Москва. 387-415.

Шейгал, Е.И. 2004. Семиотика политического дискурса. Москва. 